
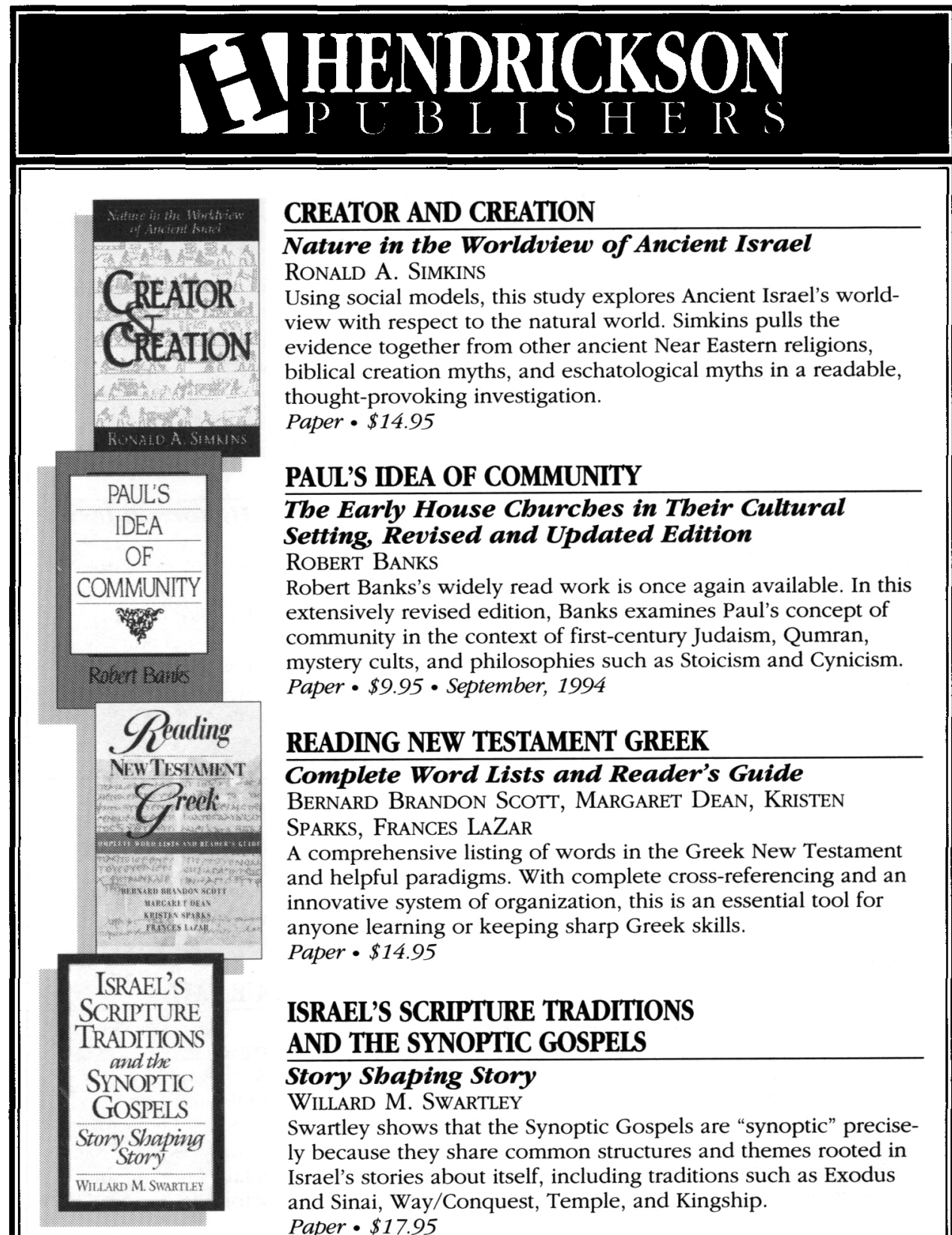

\title{
CREATOR AND CREATION
}

Nature in the Worldview of Ancient Israel

RONALD A. SIMKINS

Using social models, this study explores Ancient Israel's worldview with respect to the natural world. Simkins pulls the evidence together from other ancient Near Eastern religions, biblical creation myths, and eschatological myths in a readable, thought-provoking investigation.

Paper $\mathbf{\$ 1 4 . 9 5}$

\section{PAUL'S IDEA OF COMMUNITY}

\section{The Early House Churches in Their Cultural} Setting, Revised and Updated Edition

ROBERT BANKS

Robert Banks's widely read work is once again available. In this extensively revised edition, Banks examines Paul's concept of community in the context of first-century Judaism, Qumran, mystery cults, and philosophies such as Stoicism and Cynicism. Paper • \$9.95 - September, 1994

\section{READING NEW TESTAMENT GREEK}

\section{Complete Word Lists and Reader's Guide}

Bernard Brandon ScotT, Margaret Dean, Kristen

SPARKS, FranCES LAZAR

A comprehensive listing of words in the Greek New Testament and helpful paradigms. With complete cross-referencing and an innovative system of organization, this is an essential tool for anyone learning or keeping sharp Greek skills.

Paper $\mathbf{\$ 1 4 . 9 5}$

\section{ISRAEL'S SCRIPTURE TRADITIONS AND THE SYNOPTIC GOSPELS}

\section{Story Shaping Story}

WILLARD M. SWARTLEY

Swartley shows that the Synoptic Gospels are "synoptic" precisely because they share common structures and themes rooted in Israel's stories about itself, including traditions such as Exodus and Sinai, Way/Conquest, Temple, and Kingship.

Paper $\cdot \$ 17.95$ 

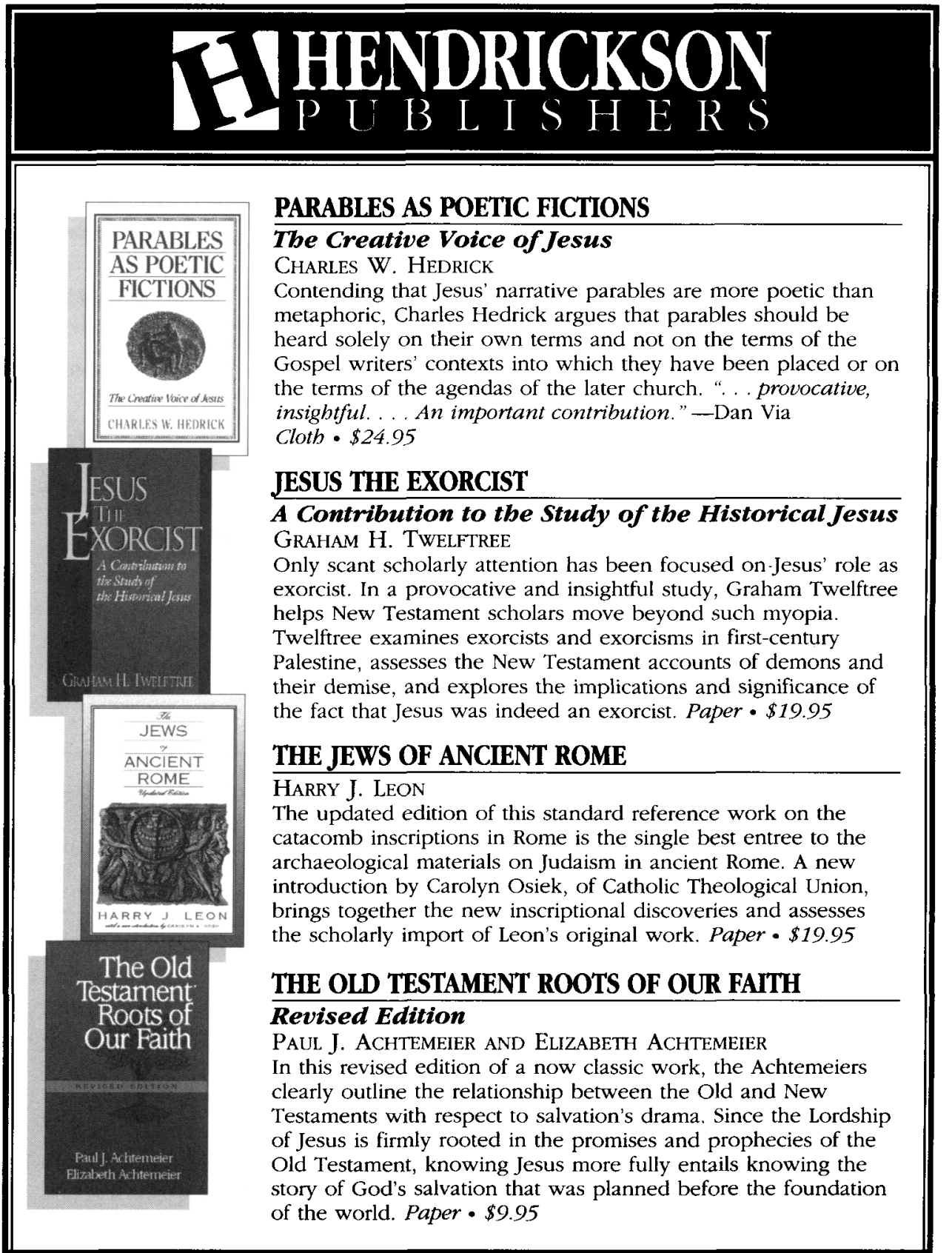

Alailable al your bookstore. or call loll-free $800-359-3111$

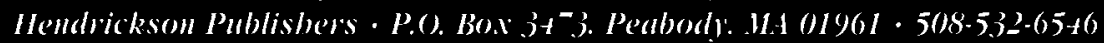




\section{FIHENDRICKSON P I B L I S I I F R S}

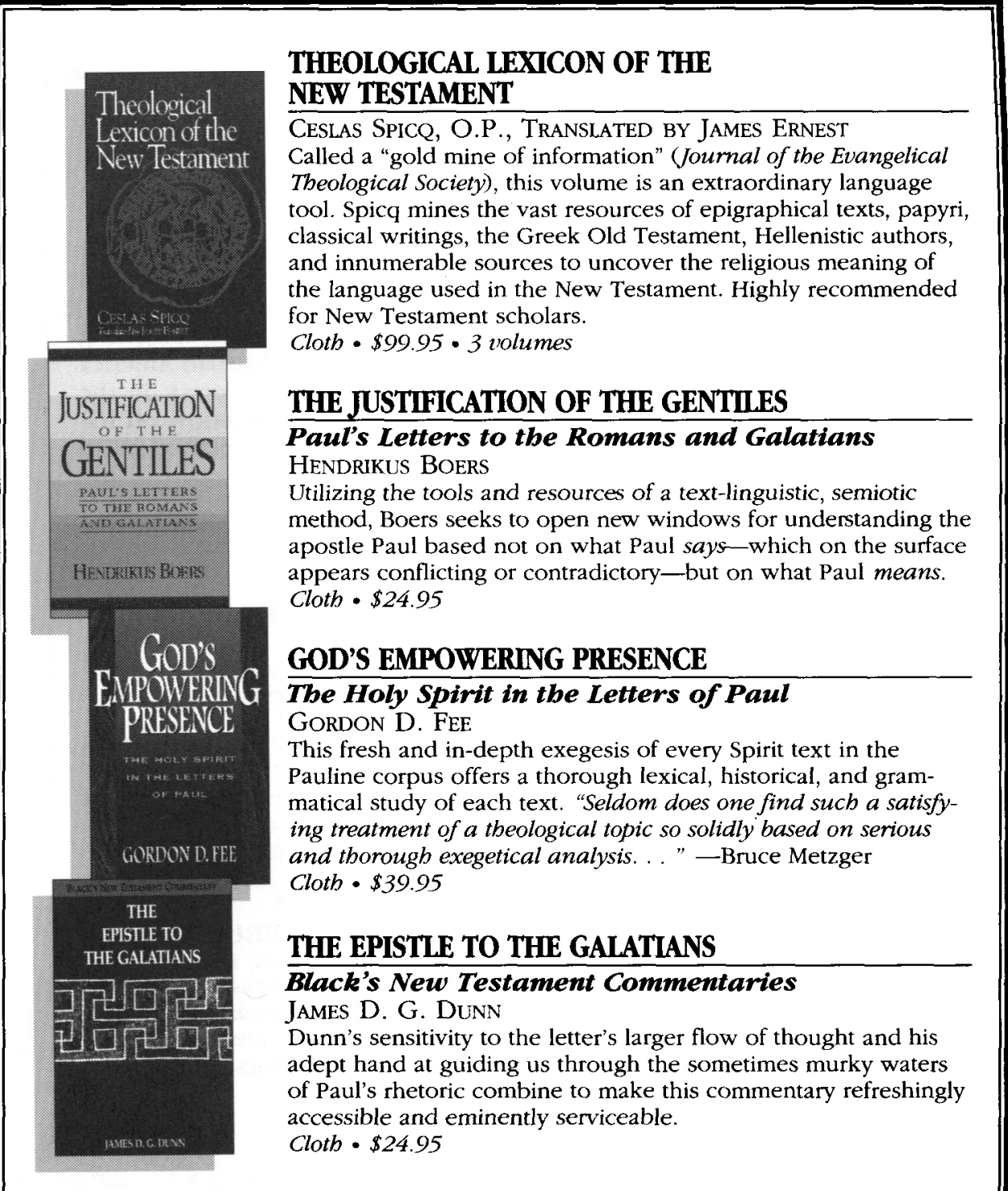

1tailable at your bookstore. an call toll-free s010-359-3111

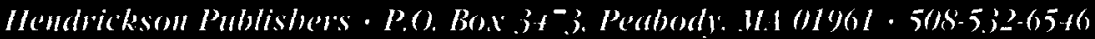




\section{Harvard Theological Studies}
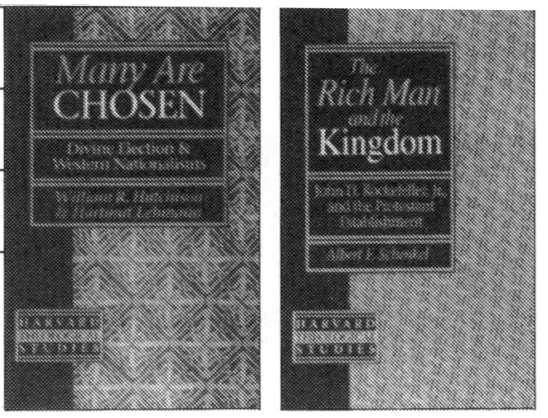

\section{MANY ARE CHOSEN Divine Election and Western Nationalisms WILLIAM R. HUTCHISON} and HARTMUT LEHMANN, Editors

Contributors explore how religious symbolism, especially the biblical rhetoric of "chosenness," figured in the formation of nine nationalist ideologies: South Africa, Switzerland, France, Germany, Israel, the United States, African Americans, Great Britain and Sweden.

176 pages, $\$ 16.00$ paper, Code 1-7091

\section{THE RICH MAN AND THE KINGDOM} John D. Rockefeller Jr. and the Protestant Establishment ALBERT F. SCHENKEL

Schenkel investigates this century's foremost religious philanthropist, who hoped to use his staggering wealth to fund "a Christian America that could stave civil unrest. In the process he opens a window on the self-understanding of liberal American Protestantism

192 pages, $\$ 14.00$ paper, Code $1-7092$
STANISLAS LUBIENIECKI

\section{HISTORY OF THE}

\section{POLISH REFORMATION}

And Nine Related Documents

Translated and Interpreted by GEORGE HUNTSTON WILLIAMS

Williams here presents the vital data and documents for understanding the religious ferment that overtook Poland in the sixteenth century. Williams has annotated and translated from Latin and Polish ten core documents from the period, chief among them Lubieniecki's History of the Polish Reformation. With 250 illustrations and commentaries. 1008 pages, $\$ 110.00$ cloth, Code $1-7085$

\section{SOMEBODYNESS}

Martin Luther King, Jr., and the Theory of Dignity

GARTH BAKER-FLETCHER

Baker-Fletcher probes King's focal notion of "somebodyness" for a contemporary theory of dignity and for dealing with sexism, denigration of black males, and gang violence.

160 pages, $\$ 12.00$ paper, Code 1.7087

\section{RELIGION AS A PROVINCE OF MEANING \\ The Kantian Foundations of Modern Theology}

ADINA DAVIDOVICH

Davidovich reconfigures Kantian scholarship by demonstrating how the chief lines and import of his work on religion have been misunderstood. 304 pages, $\$ 18.00$ paper, Code $1-7090$

\section{THE LEGACY OF}

\section{H, RICHARD NIEBUHR}

RONALD F. THIEMANN, Editor

Essayists in this volume assess Niebuhr's contributions in four areas: confessional identity, theological method, church history, and social ethics.

152 pages,

$\$ 15.00$ paper,

Code 1-7084

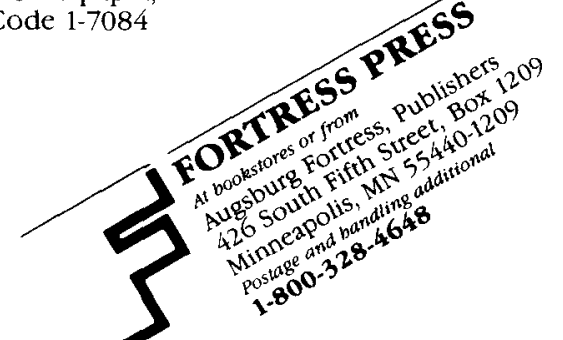




\section{7:4 OCTOBER 1994}

377 Lessons from the Dying: The Role of Deuteronomy 32 in its Narrative Setting

Steven Weitzman

395 Canon Formation and Social Conflict in Fourth-Century Egypt: Athanasius of Alexandria's Thirty-Ninth Festal Letter

David Brakke

421 Condemnation to the Mines in the Later Roman Empire Mark Gustafson

435 The Coptic Wizard's Hoard Paul Mirecki

461 Self-Cognizing Intellect and Negative Attributes in Maimonides' Theology

Hannah Kasher

473 Summaries of Doctoral Dissertations

485 Books Received 